\title{
German Shakespeare and the Political Stage
}

\author{
Pavel Drábek
}

Peter W. Marx. Hamlets Reise nach Deutschland: Eine Kulturgeschichte. Berlin: Alexander Verlag Berlin, 2018. 435 pp. ISBN 978-3-89581-480-7.

Peter W. Marx. Macht|Spiele: Politisches Theater seit 1919. Berlin: Alexander Verlag Berlin, 2020. 223 pp.

ISBN 978-3-89581-516-4.

Jeder Hamlet hat ein Buch in der Hand. Aber was für ein Buch liest der Hamlet unserer Zeit?'” (Jan Kott in MARX 2018: 259)

Over a period of three years, Peter W. Marx has published three substantial volumes. Apart from the two monographs under review, there is also a remarkable edited collection, Dokumente, Pläne, Traumreste: 100 Jahre Theaterwissenschaftliche Sammlung Köln [Documents, Layouts, Remaining Dreams: 100 Years of the TWS Theatre Studies Collection Cologne] (2020), a richly illustrated book dedicated to the centenary of the Theatre Studies Collection at the University of Cologne, of which Marx has been director since 2012. Clearly this flurry of publishing activity marks a summative moment of German history, society, and culture that have been closely interlinked with the theatre. As the two reviewed books amply document, Shakespeare's works - especially his tragedies and histories - have been the metaphysical companion of the last three tumultuous centuries. That is true of Hamlet in particular: 'Deutschland ist Hamlet,' Ferdinand Freilingrath declared famously in his 1844 poem (cited and discussed in Chapter 2 of Marx's Hamlets Reise). It is

1 'Every Hamlet has a book in his hand. But what kind of book does the Hamlet of our time read?' (transl. by P. Drábek). remarkable how that one play has served for some two hundred and fifty years as the matrix of questions and probe of political, cultural, and personal self-reflection in Germany.

The two books - Hamlets Reise nach Deutschland: Eine Kulturgeschichte [Hamlet's Journey to Germany: A Cultural History] and Macht|Spiele: Politisches Theater seit 1919 [Power|Plays: Political Theatre Since 1919] - are interconnected in this sense. The former (and heftier) volume focuses on Hamlet, the German arch-play that has behaved as the oracle that generations have tried to decipher. Marx doesn't use this mythological imagery although it is apparently lurking behind the serious study; he operates with Hans Blumenberg's incisive philosophy of history and metaphorics to write a history of German theatre. This history is not linear in the sense of a logical, millennial development - a grand narrative towards a common goal; neither is it reducing individual eras and styles to some essentialised -isms. What provides continuity is the grand metaphor of Shakespeare's plays that pose questions and invite varieties of time-specific answers. Hand in hand with Blumenberg's philosophy, for Marx at the heart of the process is not a development of a given essence - a core of an eternal 
truth - but negotiations in which one can understand and recognise different claims and responses to identical questions (to paraphrase Marx on p. 14). In this way, Hamlet provides that set of questions turning its stagings into a kind of Enlightenment interrogation of its world, its society and its inhabitants.

The two books under review share this methodological and historiographic approach. Their subjects are distinct but significantly overlap: Hamlet is the focal point of the former, while in the latter, Shakespeare's plays inform the majority of the productions discussed. Also, just over halfway through Hamlets Reise, the two books start blending: as the dramatic text starts disintegrating in the experiments of the 1970 s, what is and is not Hamlet (or Shakespeare or any other play for that matter) is becoming increasingly difficult to say. At that point, 'Shakespeare' is a common point of reference, an impartial vocabulary in a corrupted, complex, and compromised mire of a world. It is the production itself its action, its imagery and metaphorical resonances - that constitute the theatrical event rather than the title of the piece.

Hamlets Reise starts in the $1770 \mathrm{~s}$, with the rise of the German civic theatre, profoundly inspired by David Garrick's acting style as well as his revival of Shakespeare as the sublime canon. Shakespeare became a guide to refine one's humanity and sensibility as well as one's political awareness. This Enlightenment approach to Shakespeare and his characters holds the various dramatis personae up as paragon humans that can help edify the general public and inspire intellectuals to become better and active citizens. The Enlightenment agenda counteracted the decadent conventions and theatrical traditions - the superstitious and obscurantist practices that survived in the popular styles, as Marx analyses in a remarkable set of instances.

The synchronous coexistence of the older traditions (several reaching deep into the Middle Ages) and the Enlightened theatre that tried to break away from their perceived idolatry is a fascinating subject of theatre history across centuries - and it is somewhat regretful that this dialectical tension does not appear more often throughout the two books. Is not history always an inconclusive negotiation of the present predicament and one's cultural histories and legacies? Emblematised in Hamlet's comparison of the two pictures, of his father and that of his uncle, comparing 'Hyperion to a satyr' (Hamlet 1.2.140) - that is the central metaphor of what we believe in, remember and aspire to in our imagination on the one hand, and what we are confronted with in the reality in front of our eyes on the other. In this way Shakespeare's Hamlet as a play, as well as Hamlet as protagonist, has played the emblem of cultural aspiration (Sehnsuchtsfigur) in countless variants, metamorphoses, and transmutations. While Hamlets Reise remains focused on that one play as an insightful and well-justified prism of German cultural history, Macht|Spiele draws on Shakespeare's other plays - as well as a few other classics, with an Aeschylus, a Schiller, or a Kleist thrown in to widen the scope (the one outlier being William Kentridge's The Head E The Load) - as timeless prompts to reflect on the times. These plays become the book that Hamlet is reading, to respond to Jan Kott's rhetorical question cited in the motto of this review. The individual details and interpretations of the productions and the political circumstances are inspired and 
suggestive. And yet, especially as both the books progress (or perhaps as we are coming closer to our own predicament of the early $21^{\text {st }}$ century), the message is beginning to look like déjà vu. Is it because we know the grand narrative of history from the fall of the German Empire at the end of World War I, the vagaries of the Weimar Republic, the ascendance and eventual traumatic defeat of National Socialism, through the Cold War to the 'End of History' and its re-emergence after the Millenium? In a sense, the remarkable productions that Marx analyses and discusses turn into museum pieces that enact an allegory of German cultural and political history. True, many of their makers were remarkable and exceptional creators and Marx painstakingly acknowledges and displays their unique qualities. However, coming together to form a single canvas of a German cultural history or German political theatre, they paradoxically lose the name of action and become 'bystanders' - mere figures in the grand matrix of historical questions. Is this loss inevitable? Can one write theatre history without subduing the rawness of the theatrical event that always happens here and now?

Both books are clearly written for a German readership, so taking them out of their language and necessarily their cultural context is a bit of epistemic violence on my part. German civic (or national) theatre has always been, since its establishment in the late $18^{\text {th }}$ century, an 'inside job'. The German public sphere (Öffentlichkeit), both as a space and as a social reality, has always been shaped by the theatre, and the theatre has always been the forum to debate "who are we, what have we done, and where are we going?' The question then is, naturally, how much of this fascinating and rich culture can cross national boundaries (without the epistemic violence I am committing) and, vice versa, how much of it can stand without a transnational perspective. It was especially in the recent productions discussed by Marx that the national cracks became more pronounced - not only with the international ritual of post-colonialism staged by William Kentridge in The Head E The Load (2018), discussed in wonderful detail in Macht|Spiele, but also in the more distant Hamlet of Piet Drescher (Potsdam, 1983), discussed in Hamlets Reise, which seemed to me incomplete without its contemporaries abroad, namely Janusz Głowacki's Fortynbras sie upit [Fortinbras Gets Drunk] written in 1982 but published in exile in 1990. Aren't a cultural history and a political theatre two concepts that impose themselves on the material and tend to lead to the grand narratives that Marx sets out to eschew at the start of his thought-provoking and well-researched books?

\section{Acknowledgements}

I would like to thank Josh Overton and Svitlana Shurma for kindly reading through my review and copy-editing it.

\section{Bibliography}

MARX, Peter W. (Hrsg.). 2020. Dokumente, Pläne, Traumreste: 100 Jahre Theaterwissenschaftiche Sammlung Köln. Berlin: Alexander Verlag, 2020 . 